\title{
Empirical Study of the Causes of Valuation Variance and Inaccuracy in Nigeria
}

\author{
C. A. Ayedun (Corresponding author) \\ Department of Estate Management, Covenant University \\ Ota, Ogun State, Nigeria \\ Tel: 234-803-390-0681Ｅ-mail: caayedun@yahoo.com \\ S. A. Oloyede \\ Department of Estate Management, Covenant University \\ Ota, Ogun State, Nigeria \\ Tel: 234-803-472-2469 E-mail: samoloye49@yahoo.com
}

O. D. Durodola

Department of Estate Management, Covenant University

Ota, Ogun State, Nigeria

Tel: 234-803-610-5028Ｅ-mail: dan_ass@yahoo.com

Received: December 13, 2011

Accepted: February 15, 2012

Published: March 1, 2012

doi:10.5539/ibr.v5n3p71

URL: http://dx.doi.org/10.5539/ibr.v5n3p71

\begin{abstract}
The question about accuracy and consistency in valuation practice has been subject of interest to the academicians, professionals and users of valuations not only in Nigeria or developing countries alone but also in the developed countries of the world such as UK, USA, Canada and Australia. Property valuation is the core of Estate Surveying and Valuation profession. Thus its accuracy and/or reliability is critical to the valuers, their clients and the stakeholders of valuation in general. Earlier studies have confirmed the existence of inaccuracy and inconsistency of valuations in these countries including Nigeria. However, there has not been much study into the factors contributing into inaccuracy and variance in the valuation estimates by the Nigerian valuers. Hence, this study aims at examining the causes of inaccuracy and variance in the country's valuation practice. To achieve the objective of the study, the use of survey method in conjunction with personal interviews with some members of the Nigerian Institution of Estate Surveyors and Valuers in practice and academic institutions in some universities and polytechnics Lagos metropolis were used for the purpose gathering data for the study. The data collected were analyzed with the aid of simple statistical tools. The findings revealed divergent causes of valuation inaccuracy and variance ranging from dearth of market data to lack of adequate training and experience on the part of the valuers and many more. The paper concluded by recommending the establishment of functional property data bank and promotion of the use of valuation standards by the Nigerian Institution of Estate Surveyors and Valuers and Estate Surveyors and Valuers Registration Board of Nigeria the bodies responsible for the regulation of valuation practice in Nigeria.
\end{abstract}

Keywords: Valuation accuracy, Valuation variance, Reliability, Consistency, Lagos metropolis, Nigeria

\section{Introduction}

Valuers and the valuation process have recently been the focus of debate and controversy in many areas of the world including Nigeria. This study concentrates on one part of the debate, investigation of the causes of valuation variance and inaccuracy.

Much of the country's wealth lies in real estate property. Thus the Estate Surveyors and Valuers who are saddled with the responsibility of contributing their professional expertise to effective and efficiently utilizing this scarce 
and vital resources (Udoetuk, 2009). Property valuation is the core of Estate Surveying and Valuation profession. Property valuation performs an essential role in property transactions. It provides advice on prospective purchases and sales in addition to supplying material information to underpin property lending decisions. Moreover, since early 1960s, property valuations have been used to proxy the exchange price of property investments for performance measurement purposes.

Valuation has been described as the "estimate or prediction of the most likely selling price" according to Baum and Crosby (1988). Implicit in the definition is the reason for valuation, which is that of acting as a proxy for market price or as a substitute for having to sell an asset. The need for valuation arises from the peculiar nature of real estate and real property markets which are heterogeneous and imperfect in nature and character. If the property market were to be perfect and real property homogenous in nature, there would be no need for valuation (Aluko, 1998). Unfortunately, the property market is anything but perfect. Unlike investment performance measurement of equities and bonds that are based on actual transaction prices that are readily available; there are little or no transaction-based prices for real property. As such, valuations are required to serve as proxy for actual selling prices in the measurement of investment performance of real property assets.

It was in 1987, in the wake of some well publicized research works by actuaries Hager and Lord that Drivers Jonas first sponsored Investment Property Databank (IPD) to carry out detailed research into valuation accuracy in the United Kingdom. Royal Institute of Chartered Surveyors (RICS), as the valuers' professional body, later took over the role as sponsor. In doing so, they were adopting one of the principal recommendations of Sir Bryan Carlsberg's Working Party on valuation practices.

In 1985, Udo-Akagha, one of the leading estate surveyors and valuers in Nigeria, while writing a foreword to "Guidance Notes on Property Valuation" noted that "there ought to be no reason why two or more valuers valuing the same interest in a property for the same purpose and at the same time should not arrive at the same or similar results if they make use of the same data and follow the same valuation approach".

In the same vein, in 1998, an editorial on page 2 on "property valuation and the credibility problems" in The Estate Surveyor and Valuer, the professional Journal of the Nigerian Institution of Estate Surveyors and Valuers stated inter alia that "the valuation process has been the focus of recent debate and controversy both within and outside the profession as cases of two or more valuers giving different capital values with wide margins of variation for the same property abound".

Comments of this nature have led many to wonder whether estate surveyors and valuers are interpreters or creators of values. From the forgoing commentaries, it is evident that the twin problems of inaccuracy and inconsistency (variance) in the valuation practice exist in Nigeria just as is the case in developed countries such as Britain, Australia, Canada and USA, Parker (1993), Baum et al (2000), where the valuers' estimates, methods and processes have been subject of intense criticisms over the past decades from clients seeking advice in increasingly sophisticated investment markets (Baum \& Macgregor, 1992).

There has been serious focus on the seeming inability of valuation estimates emanating from professional valuers to accurately represent/interpret market prices or serving as a reliable security instruments/documents for bank loans. Bretten and Wyatt (2002) observed that valuers do not operate with perfect market knowledge while valuers in many instances follow clients' instructions, analyze available information, make judgments and respond to different pressures from stakeholders when preparing a valuation in a market atmosphere of heterogeneity.

The essence of the study is to address the above issues and problems by focusing mainly on the questions of reliability/consistency benchmarks and the nature and causes of reliability and consistency of the professionally prepared investment valuations in the Lagos metropolitan property market. This is with a view to improving on the accuracy and consistency level of the investment valuations prepared by the estate surveyors and valuers in Nigeria.

\section{Review of Relevant Literature}

Valuation accuracy literature was actually triggered by the paper authored by Hager and Lord (1985) and which was submitted to the Institute and Faculty of Actuaries in reaction to Investment Property Databank's (IPD) use of valuation as a performance measure for investment properties in the UK. They requested ten valuers to carry out the valuation of two properties consisting of a rack rented office property and a reversionary retail unit property. They expected that the range of valuations for a particular property would bew about $5 \%$ either side of the control valuation, carried out by an expert valuer. The resulting valuation estimates from the respondent valuers when compared with the valuation estimates by the expert valuer revealed that for the office property, four of the ten valuations produced figures within $5 \%$ of the control valuation. Five out of the remaining six valuations were within $10 \%$. With regard to the retail unit, half of the valuations were within $5 \%$ of the control valuation, while two 
of the remaining five were within $10 \%$. None of the valuations produced a variation of greater than $13.2 \%$. The authors' conclusion was that valuations were not reliable for the purpose of performance measurement in Britain. Clearly, however, no meaningful conclusions could be reached with just two properties. Nonetheless, the paper had a significant adverse influence on the views of fund and investment managers on the property market. Since then, this topic has received much attention from both investment and academic community.

Brown (1985) conducted a larger and much more rigorous study on a sample of 29 properties for which there were transaction prices and recent prior valuation figures. In the study, independent valuation firms were made to carry out the valuations of the subject properties. Both valuations and sale transactions took place between 1975 and 1980 . In addition, both the valuations and the sale transactions were based on the RICS definition of Open Market value, which excludes special purchases, forced sales etc. The author used regression analysis to compare valuation estimates and sale prices on the 29 sampled properties. However, the number of properties sampled for the study is considered too small to be able to draw unbiased conclusions.

IPD/Drivers Jonas (1988) also adopted a regression based procedure, but made use of a much larger sample size of 1,442 properties, all of which were sold between January 1982 and March 1988. Each of these properties had at least two (2) open market valuations prepared in respect of them in the two consecutive years preceding their sales, with all the valuations undertaken between January 1980 and December 1987. They analyzed these samples with the inverse of the IPD/Drivers Jonas procedure (the least square model regressed price on value). This study also found a high correlation of $93.4 \%$ between valuation estimates and transaction prices $\left(\mathrm{R}^{2}=93\right)$ suggesting a high level of valuation accuracy.

In 1990, IPD/DJ updated their study with a larger analysis of 2,400 properties for which there were transaction sales figures and valuation estimates. The study still observed high correlations between valuation estimates and sale prices as earlier found in their 1988 study, thus further supporting an UK (IPD/DJ, 1990) study. However, Lizieri and Vienmore-Rowland (1991) questioned the regression based statistical methodology adopted by IPD/Drivers Jonas and Brown for their studies drawing attention to its inherent flaws (a problem known as heteroascidity). Despite this criticism, IPD and Driver Jonas continuously updated their regression based studies in 1992, 1994, 1996, and lately 2004 with increased sample sizes, analysis period and range of statistical analyses employed. Results obtained consistently maintained the same basic findings concerning high levels of valuation accuracy. The Lizieri and Venmore-Rowland (1991) criticism exposed the statistical validity of studies of the IPD/DJ which employed simple regression analysis to find high levels of valuation accuracy (see, for example, Brown, 1992). In the same way, the potential role of behavioural research in the determination of valuation accuracy debate has been suggested to questioning too (Waldy, 1997).

Matysiak and Wang (1995) employed standard deviations in their analysis of 317 sets of valuation estimates and transaction prices data covering the period of 1973 to 1991. Following the extensive statistical discussions and manipulations, the authors found that the probability of achieving a selling price within $+/-10 \%$ of the valuation estimate was only $30 \%$, rising to a probability of $55 \%$ within $+/-15 \%$ of the valuation and $70 \%$ within $+/-20 \%$ of the valuation estimates. The authors also went on to examine the propensity of valuers to overvalue in falling markets and undervalue in rising markets. The study noted that "given the indicative evidence for the significant impact of the bull/bear market environments in conditioning the valuation figures, more analysis is required in eliciting the relationship between valuer's behaviour and changing market conditions" (Matysiak \& Wang, 1995). However, whilst the Matysiak and Wang (1995) findings would appear to undermine those of other studies concerning high levels of valuation accuracy relative to transaction sales, the complexity of the statistical analyses adopted renders a full appreciation of the findings challenging as not too many people can handle some of the statistical tools employed in their study.

Hutchison et al (1995) surveyed five national valuers and five local valuers for each of 14 centres in UK, seeking valuations at no fee for a range of hypothetical retail, office and industrial buildings with particular characteristics in actual locations and with standard leases. Valuation variation (consistency) rather than accuracy (reliability) was examined. They found differences in the variance of valuation between national and local valuation firms $(8.63 \%$ and $11.86 \%$ respectively for national and local firms). The authors discovered that over $80 \%$ of all the valuations produced a variation from the mean of less than $20 \%$, which is a wider valuation variation than that suggested by Brown's (1991) earlier study. The results of the study are however open to question as the valuers were paid no fee and moreover, the properties considered were hypothetical.

Mokrane (2002) addressed the twin issues of valuation accuracy and consistency in five European countries (UK, France, Sweden, Netherlands and Germany). In these countries, he considered time periods of 1990 to 2000 in UK; 2,000 properties over the period of 1999 to 2000 in France; 1,800 properties over the period of 1997 to 2000 of 
Sweden; 5,700 properties over the period of 1999 to 2000 in Netherlands; and 400 properties over the period of 1997 to 2000 in Germany. The accuracy tests made provision for the adjustment of previous valuation for market movements and capital expenditures and receipts that may have taken place between the valuation date and transaction date. With regards to accuracy, he came up with conclusions that there exists only a short "distance" between transaction sales and adjusted valuations in the respective countries, though valuation estimates differed from sale prices. With regards to consistency, he found that in most of these countries, the degree of variation was low and the change-in-valuer effect was statistically significant.

Bretten and Wyatt (2002) investigated the extent and possible causes of variance in property investment valuation for commercial lending purposes within UK using questionnaire survey circulated to 220 lenders, finance brokers, valuers, property companies and institutional investors involved in commercial property valuation process in order to gauge professional opinion. They observed that the main cause of variance was the individual valuer's "behavioral influences" and that parties to a valuation instruction widely accept "the margin of error" principle. Their study concluded that variance can enter the valuation process at any stage, from the issuing of instruction letters and negotiation of fees through to external pressure being exerted on the valuer when finalizing the valuation figure. Although the study circulated to 220 individuals involved in the commercial property valuation process, they however did not involve the court officials. This study considered this very necessary and involved 6 court officials ( 5 judges and one court registrar) in addition to other individuals involved in the commercial property valuation process. In addition, their survey failed to recognize the need for the use of real life valuation and sale figures and for this reason, this study made use of valuation and sale figures of 131 real lives recently valued and sold properties in addition to the valuation of 12 selected properties valued by 45 valuers.

Crosby, Devaney, Key and Matysiak (2003) identified whether the 2002 sales in the IPD Monthly index threw any light on whether the sale price was known before the completion date or if in their study of timing of the valuation and sale data in UK uses valuations and sales data from the sale was agreed before completion date. The study concluded that timing issues had been identified as one of the technical difficulties in producing definitive results on differences between prices and valuations.

Generally, the UK review shows that there have been contradictory findings over the years. Researchers such as Hager and Lord (1985), Matysiak and Wang (1995) and Hutchison et al (1995) seem to suggest that valuations are inaccurate and inconsistent (especially if one adopts a maximum margin of error of $+/-10 \%$ ), while authors such as Brown (1985), IPD (1988, 1990, 1992, 1994, 1996, 2004), and Mokrane (2002) felt otherwise. The difference appears dependent on the statistical methodology employed. Whilst the high accuracy/variation advocates employed regression based procedures, the low accuracy/variation advocates employed mean/standard deviations. Even then, general conclusions are difficult to make because of the heteroascidity problems with the regression based procedure and the problem of an acceptable maximum bracket of error with the standard deviation approach.

From the 1980s, literary (albeit non empirical) comments began to be made on the accuracy of valuations in Nigeria. A past President of the Nigerian Institution of Estate Surveyors and Valuers, Udo-Akagha (1985) as noted earlier in his foreword to the first edition of the Guidance Notes on Property Valuation posited that "there can be no reason why two or more valuers, valuing the same interest in a property for the same purpose and at the same time should not arrive at the same or insignificantly different results if they make use of the same data and follow the same valuation approach. But very often this is not usually the case and in some of these unfortunate cases, the profession is thrown into considerable embarrassment".

The above quotation captures the growing concern among valuers and their clients at the time. Estate Surveyors and Valuers were faced with increasing allegations of wide variations in the valuation estimates supplied by them. Similar comment was made by Igboko (1992) who while researching into the investment method of valuation in Nigeria, at the instance of the Nigerian Institution of Estate Surveyors and Valuers (NIESV), observed what he described as a "weak grasp of valuation" amongst the valuation practitioners. He came to a conclusion that many of the investment valuations conducted were actually "mis-valuations" and "guesstimates". He did not however provide any credible empirical statistical basis to justify his conclusions.

Ogunba (1997) undertook an empirical step at addressing the question of accuracy and variance in investment valuations in Nigeria using Lagos metropolis as the study area. In the absence of a database of property valuations and sales, he resorted to the approach of requesting thirty Lagos based practicing estate surveying and valuation firms to carry out valuations of two residential properties earlier sold located at Victoria Island and Ikoyi respectively. The valuation estimates subsequently arrived at by the valuers was subjected to a number of statistical tests such as range, inter-quartile range, mean deviation and regression/correlation analysis. The result of the statistical tests showed that valuations were not good proxy for market prices, for three reasons. First, the average variance between valuations and prices was far in excess of his adopted margin of error of $+/-5 \%$; the intercept in 
the regression equation was statistically distinguishable from zero and the slope statistically distinguishable from 1; and third, the range and inter-quartile ranges were unacceptably wide. Based on these observations, the results of the study must be interpreted with caution because only two (2) properties were considered (as in the Hager and Lord, 1985 study) and the sample of valuers (thirty firms) was small. In addition, the properties were never inspected nor were the valuers paid for their services.

Aluko (2000) carried out an accuracy study on a larger scale with a focus on mortgage valuations and subsequent sale prices of such mortgaged properties used as collateral securities. In his study, Bank records of mortgage valuations conducted by fifty nine (59) estate firms in Lagos metropolis were examined. The sale prices of the properties were compared with their earlier valuation estimates and analyzed by means of regression/ANOVA. He came to a conclusion that valuations in Nigeria are a good proxy for price and that despite the anecdotal evidence to the contrary the mortgage valuers are doing a very good job of price prediction.

Ogunba (2003) expanded the coverage area of accuracy studies to a consideration of property valuation estimates and sale prices in the six States of Southwestern Nigeria. The approach adopted in the study was similar to the one adopted in his earlier work. Statistical tests such as range, inter-quartile range, mean deviation, regression analysis, and analysis of variance employed by the author confirmed his earlier work that valuation estimates were not good proxy for sale prices and also that valuation estimates of one firm were not good proxy of other firms.

Adegoke (2008) investigated valuers' behavior in Nigeria when valuing properties in localities that they lack substantial prior experience in Nigeria. He sampled 122 estate surveying and valuation firms in Lagos metropolis. He used quasi-experimental and survey methods for the study. The researcher employed simulated valuation method in carrying out valuation of a single commercial office property located in a city that the participants/respondents were not familiar with. The study revealed a wide variance of valuation outcomes from the mean which showed that the valuation outcomes were not reliable. While the study used only a single property for valuation experiment and only supplied the participants with description of the property, this study made use of participant valuers who were requested to value 12 recently sold properties with a view to comparing their valuation outcomes with the sale figures of the properties and at the same ascertain the various valuation inputs comprising of outgoings, rental values and yield rates adopted by each of the valuers involved.

\section{Study Area}

Lagos State covers an area of about 3,577 square kilometers, representing $0.4 \%$ of Nigeria's territorial landmass according to Esubiyi (1994). The State shown in Figure 1 below shares boundary in the North with Ogun State, West with the Republic of Benin, and stretches for over 180 kilometers North of the Guinea Coast of the Atlantic Ocean. Politically, Lagos State according to Ogunba (1997) had expanded as a result of rural-urban drift and had become a metropolis enclosing settlements such as Mushin, Oshodi, Ikeja, Agege, Shomolu and Bariga. The 2006 National census put the population of the State at 9,013,534.

Lagos metropolis has been chosen as the study area because it is the most important commercial city in Nigeria thus providing a sufficiently vibrant economic base and valuation activity which the researcher hopes to provide a vigorous and robust study base. Lagos metropolis, apart from being Nigeria's former capital, is the largest metropolitan city in Africa. The metropolis is located within the coastal frontage of Lagos State and is bounded in the West, by the Republic of Benin, in the East by Ondo State and Atlantic Ocean in the South and in the North by Ogun State. The metropolis covers an approximate land area of 2,350 square kilometers spreading over four main islands of Lagos, Iddo, Ikoyi and Victoria islands.

In the economic scene, Lagos metropolis has grown from a small farming and fishing settlement to become an important centre of commerce, finance and maritime in Nigeria, housing the headquarters of several banks, industries and commercial enterprises. According to the NIESV Directory (2009), most Estate Surveyors and Valuers aggregate around major business districts of the metropolis such as Lagos Island, Ikeja, Apapa/Ijora, and Lagos Mainland where there is the expectation of a very active property market.

\section{Research Methodology}

The research study population comprises of the estate surveying and valuation firms in Lagos metropolis, which constitutes about fifty percent of practicing firms in Nigeria according to the Dirctory of the Nigerian Institution of Estate Surveyors and Valuers (2009). A total of 120 registered estate surveyors and valuers out of 268 firms with either their head or branch offices in Lagos State were randomly selected for the study and out of this number 82 responded by returning the questionnaire administered on them duly filled found useful for the study. The data so collected were analyzed with the aid of simple statistical techniques. In addition, personal interviews were conducted with some key officials of the Nigerian Institution of Estate Surveyors and Valuers (NIESV) and Estate 
Surveyors and Valuers Registration Board of Nigeria (ESVARBON), the two bodies responsible for regulation of estate surveying and valuation practice in the country.

\section{Findings and Discussion}

The data collected with the aid of questionnaire administered on the respondents are analyzed as presented in tables 1 to 5 . Table 1 and 2 are about the characteristics of the respondent estate surveyors and valuers. Majority of the estate firm (63\%) have experiences ranging between 1 and 10 years as can be seen from table 1 . This is clear indication that majority of practicing surveyors are not well experienced in the art and science of valuation and as it known that experience is the best teacher. The fact that majority of them are lacking relevant experience will ultimately affect their performances especially in regard to accuracy and consistency in valuation. Educationally, majority of practicing valuers were found to possess Higher National Diploma and Bachelor of Science degrees only which ordinarily should be enough for them. But in view of growing awareness and sophistication of majority clients and complexity of some valuation assignments, there is need for further study with a view to be above the happenings in the valuation industry and meet up with global valuation demands.

With regard to the number of conferences, workshops and seminars attended by the respondent estate surveyors and valuers between 2002 and 2007, it was discovered that $62 \%$ of the respondents attended average of 1 to 5 conferences/workshops/seminars within the 6 year period, $20 \%$ attended $6-10$ conferences while $15 \%$ of the respondents did not attend any. This suggests that valuers are taking time out to improve their knowledge, though the majority attendance of $1-5$ conferences/workshops/seminars cannot be seen as very sufficient.

Table 2 clearly shows that the Nigerian valuers are yet to imbibe the culture of specialization. A cursory look at the table shows that the majority ( $89 \%$ ) of respondent firms engage in general practice, as a means of survival, therefore giving no room for specialization. If we accept the argument that specialization gives rise to efficiency, then this result may suggest that most firms of estate surveyors and valuers might not be operating at the highest level of efficiency and this have the tendency of affecting their accuracy and consistency performances as only four (4\%) percent of estate surveying and valuation firms specializes in valuation. Dearth/paucity of market evidence/data and use of outdated valuation approach and techniques ranked first and second by the respondents as the factors responsible for inaccurate valuations as can be seen from Table 3. Data/market evidence is very germane to valuation accuracy and where such information is lacking, the result is inaccurate valuation figure emanating from such situation.

Table 4 ranked experience, educational background and available market information at disposal of individual valuers first, second and third respectively as the factors responsible for variance or inconsistency in valuation amongst the valuers when occasion arise for two or more valuers to carry out the valuation of the same property at about the same time. The above findings are in consonance with earlier studies such as Wyatts, (2003); Millington, (1985) in UK; Levy et al (1999) in Australia and that of Ogunba and Ajayi (1998) in Nigeria.

Table 5 shows the respondents ranking of possible solution for valuation variance/inaccuracy in the country. Creation of valuation data bank was ranked first in the hierarchy of factors required to solve the twin problems of valuation variance and inaccuracy in Nigeria while attendance of refreshers courses by the valuers; provision of up to date valuation manual and improved school curriculum/syllabus were ranked second, third and fourth respectively.

\section{Conclusion and Recommendation}

The findings from this study has revealed that the challenge for eliminating the factors responsible for valuation inaccuracy and variance in Nigeria falls across the academia, practitioners and the regulatory bodies comprising of Nigerian Institution of Estate Surveyors and Valuers and Estate Surveyors and Valuers Registration Board of Nigeria since it has been established that valuation accuracy and consistency are at the heart of clients' confidence and the profession needs to keep its house in order.

Accordingly, it is recommended that the academic steering committee of the regulatory bodies-the Nigerian Institution of Estate Surveyors and Valuers and the Estate Surveyors and Valuers Registration Board of Nigeria should join hands to fund research programmes as is the case of Drivers Jonas/IPD in United Kingdom. With such research efforts, Nigerian valuers would be able to access the global world of property valuation in this technological age.

There is the need for University administrators working in close association with the Nigerian Institution of Estate Surveyors and Valuers on one hand and the Estate Surveyors and Valuers Registration Board of Nigeria on the other enjoin University lecturers on sabbatical leave to interact closely with their colleagues in practice and vice versa. 
There is the urgent need to have a cross fertilization of ideas and experiences among lecturers and estate surveyors in public and private practices in the hope of producing graduates who can go into the business world and survive.

Property Valuation Guidance Notes was published by the Nigerian Institution of Estate Surveyors and Valuers in 1985 with a forward written by a seasoned valuer. There is the need for continuity. Updating rules and guidance notes would ginger estate surveyors and valuers to achieve enhanced accuracy, rationality and standardization if the rules and regulations are strictly enforced by the Institution without bias or favourism.

Each State Chapter of NIESV should be encouraged to establish a property data bank and forward same on agreed periods to be reviewed periodically to make such data relevant. Such information so collated could serve as a reference point for comparison between states and among States for Nigerians who may which to invest in any State within the country. Such property databank would assist researchers in producing property market indices for performance measurement and accuracy test especially in the application of the investment method of valuation. The Estate Surveyors and Valuers Registration Board of Nigeria in conjunction with the Nigerian Institution of Estate Surveyors and Valuers should define and spell out the maximum acceptable margin of error in valuations as is done in developed countries.

\section{References}

Adegoke, O. J. (2008). Valuation variance in unfamiliar locations and the significance of caution in valuer behaviour. The estate surveyor and valuer, Jounal of the Nigerian Estate Surveyors and Valuers, 31(1), 7-13

Aluko, B. T. (1998). Property valuation: Are estate surveyors and valuers interpreters or creators of values?. The Estate Surveyor and Valuer, Journal of Nigerian Institution of Estate Surveyors and Valuers. 21(2), 9-17.

Aluko, B. T. (2000). A study of appropriateness of mortgage valuation for institution lending in Nigeria. (Unpublished doctoral dissertation). The Department of Estate Management, Obafemi Awolowo University, Ile-Ife, Nigeria.

Baum, A., \& Crosby, N. (1988). Property Investment Appraisal Routledge (pp. 708-726). London: Routledge.

Brown, G. (1985). Property investment and performance measurement: A reply. Journal of Valuation, 4, 33-44. http://dx.doi.org/10.1108/eb007986

Bretten, J., \& Wyatt, P. (2002). Variance in property valuation for commercial lending. Vol. 4, No. 9, RICS Foundation May 2002 Electronic Reference PS0409 (www.rics-foundation.org).

Brown, G. (1991). Property Investment and the Capital Markets. London: E\&FN Spon.

Brown, G. (1992). Valuation accuracy: Developing the economic issues. Journal of Property Research, 9, 199-207. http://dx.doi.org/10.1080/09599919208724067

Crosby, N., Devaney, S., Key, T., \& Matysiak, G. (2003). Valuation Accuracy: Reconciling Timing of the Valuation and Sale. Helsinki-Finland: European Real Estate Society.

Esubiyi, A. O. (1994). Obsolescence and property values: A case study of Lagos. (Unpublished BSc dissertation). The Department of Estate Management, Obafemi Awolowo University, Ile-Ife, Nigeria.

Hager, D. P., \& Lord, D. J. (1985). The property market, property valuations and property performance measurement. Journal of the Institute of Actuaries, 4, 1-27.

Hutchison, N., MaCgregor, B., \& Nanthakumaran, N. (1995). Variations in the capital valuations of UK commercial property: Do valuers get it right?. RICS 1995 Cutting Edge Conference, Aberdeen, September.

Igboko, N. P. (1992). Research project on valuation methods in Nigeria with special refernce to year purchase (Y.P.). Research Report for the Nigerian Institution of Estate Surveyors and Valuers, 1, 1-43.

IPD/Driver Jonas (1988). The Variance in Valuations, Driver Jonas, London.

IPD/Driver Jonas (1990). The Variance in Valuations, Driver Jonas, London.

Levy, D., \& Schuck, E. (1999). The influence of clients on valuations. Journal of Property Investment \& Finance, 17(4), 380-400. http://dx.doi.org/10.1108/14635789910271773

Lizieri, C., \& Venmore-Rowland, P. (1991). Valuation accuracy: A contribution to the debate. Journal of Property Research, 1, 112-115.

Matysiak, G., \& Wang, P. (1995). Commercial property market prices and valuations: Analyzing the correspondence. Journal of Property Research, 123, 181-202. http://dx.doi.org/10.1080/09599919508724144

Millington, A. F. (1985). Accuracy and the role of the valuer. Estate Gazette, 276, 603. 
Mokrane, M. (2002). Valuations: Standards, accuracy and consistency. IPD European Property Strategies Conference, May, 2002.

NIESV. (2009). The Directory of the Nigerian Institution of Estate Surveyors and Valuers.

Ogunba, O. A. (1997). A study of valuation and pricing methods in the residential property market in Lagos metropolis. (Unpublished M.Sc. dissertation). The Department of Estate Management, Obafemi Awolowo University, Ile-Ife; Nigeria.

Ogunba, O. A., \& Ajayi, C. A. (1998). An assessment of the accuracy of valuations in the residential property market of Lagos. The Estate Surveyor and Valuer, Journal of the Nigerian Institution of Estate Surveyors and Valuers, 21(2), 19-23.

Parker, D. R. (1993). Aspects of a depressed property market: Some issues facing valuers. The Valuer Land Economists, 1, 370-381.

Udo-Akagha, S. (1985). Guidance Note on Property Valuation-Foreword to the Nigerian Institution of Estate Surveyors and Valuers, $1^{\text {st }}$ Edition.

Udoetuk, N. V. (2009). A critical examination of the short comings of the conventional method of valuation. Journal of Estate Surveying Research, 1(2), 89-105.

Waldy, B. (1997). Valuation Accuracy $64^{\text {th }}$ FIG Permanent Committee Meeting and International Symposium, Singapore, May.

Table 1. General Characteristics of Respondent Estate Surveyors and Valuers

\begin{tabular}{|c|c|c|c|}
\hline Parameter & Sub-Division & Frequency & Percentage (\%) \\
\hline \multirow{5}{*}{ Years of Professional Experience } & $1-10 \mathrm{yrs}$ & 52 & 63 \\
\hline & $11-20 \mathrm{yrs}$ & 13 & 16 \\
\hline & $21-30 \mathrm{yrs}$ & 6 & 7 \\
\hline & $31-40 \mathrm{yrs}$ & 7 & 9 \\
\hline & Above 40 yrs & 4 & 5 \\
\hline \multirow{5}{*}{$\begin{array}{c}\text { Highest Academic } \\
\text { Qualification }\end{array}$} & OND & 5 & 6 \\
\hline & HND & 27 & 33 \\
\hline & B.Sc & 32 & 40 \\
\hline & M.Sc & 17 & 21 \\
\hline & $\mathrm{PhD}$ & 1 & 1 \\
\hline \multirow{5}{*}{$\begin{array}{l}\text { No. Conferences/Workshops/ } \\
\text { Seminar attended } \\
\text { Between } \quad 2002 \& 2007\end{array}$} & None & 12 & 15 \\
\hline & $1-5$ & 51 & 62 \\
\hline & $6-10$ & 16 & 20 \\
\hline & $11-15$ & 2 & 2 \\
\hline & $16-20$ & 1 & 1 \\
\hline \multirow{7}{*}{ Age/experience of the Firm } & $1-5$ & 30 & 36 \\
\hline & $6-10$ & 22 & 27 \\
\hline & $11-15$ & 13 & 16 \\
\hline & $16-20$ & 9 & 11 \\
\hline & $21-25$ & 4 & 5 \\
\hline & $26-30$ & 2 & 2 \\
\hline & $31 \&$ Above & 2 & 2 \\
\hline
\end{tabular}

Table 2. Respondent's Firm's Area of Specialization

\begin{tabular}{|c|c|c|}
\hline Area of Specialization & Frequency & Percentage \\
\hline Valuation & 3 & 4 \\
\hline Property Financing and Development & 1 & 4 \\
\hline Estate Agency & 3 & 2 \\
\hline Property Management & 2 & 89 \\
\hline General Practice & 73 & 100 \\
\hline Total & 82 & 4 \\
\hline
\end{tabular}


Table 3. Respondents Perceived Reasons for Valuation Inaccuracy

\begin{tabular}{|c|c|c|c|c|c|c|c|c|}
\hline \multirow{2}{*}{$\mathrm{S} / \mathrm{N}$} & \multirow{2}{*}{ Suggested Reasons } & \multicolumn{5}{|c|}{ Respondents Responses } & \multirow{2}{*}{$\begin{array}{l}\text { Weighted } \\
\text { Mean Score }\end{array}$} & \multirow{2}{*}{ Ranking } \\
\hline & & SA & A & $\mathrm{N}$ & $\mathrm{D}$ & SD & & \\
\hline 1 & Dearth/paucity of market data/evidence & 33 & 26 & 9 & 6 & 5 & 3.82 & $1^{\text {st }}$ \\
\hline 2 & Use of outdated valuation approach and techniques & 20 & 25 & 10 & 17 & 20 & 3.46 & $2^{\text {nd }}$ \\
\hline 3 & Use of outdated valuation data & 25 & 23 & 10 & 11 & 13 & 3.44 & $3^{\text {rd }}$ \\
\hline 4 & Lack of valuation regulation and control framework & 23 & 25 & 8 & 9 & 17 & 3.34 & $4^{\text {th }}$ \\
\hline 5 & Lack of valuation standard/manual & 19 & 25 & 12 & 15 & 11 & 3.32 & $5^{\text {th }}$ \\
\hline 6 & Inadequate training & 18 & 20 & 15 & 16 & 13 & 3.2 & $6^{\text {th }}$ \\
\hline 7 & $\begin{array}{l}\text { Failure to hold valuers responsible for professional } \\
\text { negligence }\end{array}$ & 18 & 12 & 8 & 25 & 19 & 3.12 & $7^{\text {th }}$ \\
\hline 8 & Imperfection of the property market & 15 & 18 & 8 & 19 & 22 & 2.82 & $8^{\text {th }}$ \\
\hline 9 & $\begin{array}{l}\text { Problem of influence from unscrupulous clients using } \\
\text { financial, material and other forms of inducement }\end{array}$ & 11 & 10 & 22 & 23 & 20 & 2.80 & $9^{\text {th }}$ \\
\hline 10 & Lack of experience on the part of the valuers & 12 & 10 & 10 & 18 & 32 & 2.41 & $10^{\text {th }}$ \\
\hline
\end{tabular}

Table 4. Respondents Perceived Reasons for Inconsistency in Valuers Valuation

\begin{tabular}{|c|c|c|c|c|c|c|c|c|}
\hline \multirow{2}{*}{ S/N } & Suggested Reasons & \multicolumn{3}{|c|}{ Respondents Responses } & \multirow{2}{*}{$\begin{array}{c}\text { Weighted } \\
\text { Mean Score }\end{array}$} & \multirow{2}{*}{ Ranking } \\
\cline { 3 - 10 } & & SA & A & N & D & SD & Mean \\
\hline 1 & Experience of individual valuer & 35 & 25 & 7 & 6 & 11 & 3.90 & $1^{\text {st }}$ \\
\hline 2 & Educational background of individual valuer & 25 & 31 & 10 & 10 & 6 & 3.72 & $2^{\text {nd }}$ \\
\hline 3 & Available market information to each valuer & 33 & 20 & 5 & 9 & 15 & 3.60 & $3^{\text {rd }}$ \\
\hline 4 & Accessibility to valuation manual/standard & 18 & 22 & 11 & 14 & 17 & 3.12 & $4^{\text {th }}$ \\
\hline 5 & Time period devoted to the valuation assignment & 14 & 10 & 15 & 13 & 30 & 2.60 & $5^{\text {th }}$ \\
\hline 6 & Sources of market data/evidence use for the valuation & 10 & 15 & 12 & 18 & 27 & 2.55 & $6^{\text {th }}$ \\
\hline 7 & Quality of information supplied by the client & 8 & 10 & 14 & 20 & 30 & 2.34 & $7^{\text {th }}$ \\
\hline
\end{tabular}

Table 5. Respondents Suggested / Possible Solution to Valuation Inaccuracy/Inconsistency

\begin{tabular}{|c|c|c|c|c|c|c|c|c|}
\hline \multirow{2}{*}{$\mathrm{S} / \mathrm{N}$} & \multirow{2}{*}{ Suggested Reasons } & \multicolumn{5}{|c|}{ Respondents Responses } & \multirow{2}{*}{$\begin{array}{l}\text { Weighted } \\
\text { Mean Score }\end{array}$} & \multirow{2}{*}{ Ranking } \\
\hline & & SA & A & $\mathrm{N}$ & $\mathrm{D}$ & SD & & \\
\hline 1 & Creation of valuation data bank & 40 & 36 & 6 & - & - & 4.41 & $1^{\text {st }}$ \\
\hline 2 & Attendance of refresher courses & 38 & 40 & 3 & 1 & - & 4.40 & $2^{\text {nd }}$ \\
\hline 3 & Provision of valuation manual/standard & 30 & 32 & 12 & 4 & 4 & 4.0 & $3^{\text {rd }}$ \\
\hline 4 & Improved school curriculum/syllabus & 30 & 25 & 15 & 10 & 2 & 3.86 & $4^{\text {th }}$ \\
\hline 5 & $\begin{array}{l}\text { Review of entrance requirements for studying estate } \\
\text { management }\end{array}$ & 28 & 28 & 8 & 8 & 10 & 3.70 & $5^{\text {th }}$ \\
\hline 6 & $\begin{array}{c}\text { Improve standard of educating/training of the potential } \\
\text { valuers }\end{array}$ & 30 & 18 & 10 & 14 & 10 & 3.54 & $6^{\text {th }}$ \\
\hline 7 & $\begin{array}{l}\text { Review the qualifying requirement by regulating bodies for } \\
\text { the intending valuers }\end{array}$ & 20 & 18 & 17 & 10 & 17 & 3.20 & $7^{\text {th }}$ \\
\hline 8 & Compulsory CPD attendance for practicing valuers & 10 & 20 & 13 & 20 & 19 & 2.80 & $8^{\text {th }}$ \\
\hline 9 & $\begin{array}{c}\text { Encouragement of specialization amongst practicing } \\
\text { valuers in the country }\end{array}$ & 12 & 13 & 20 & 17 & 20 & 2.76 & $9^{\text {th }}$ \\
\hline 10 & $\begin{array}{c}\text { Need for strengthening of the valuation institutional } \\
\text { framework }\end{array}$ & 8 & 14 & 20 & 24 & 18 & 2.70 & $10^{\text {th }}$ \\
\hline
\end{tabular}

Note: $\mathrm{SA}=$ Strongly Agree; $\mathrm{A}=$ Agree; $\mathrm{N}=$ Neutral; $\mathrm{D}=$ Disagree; $\mathrm{SD}=$ Strongly Disagree. 


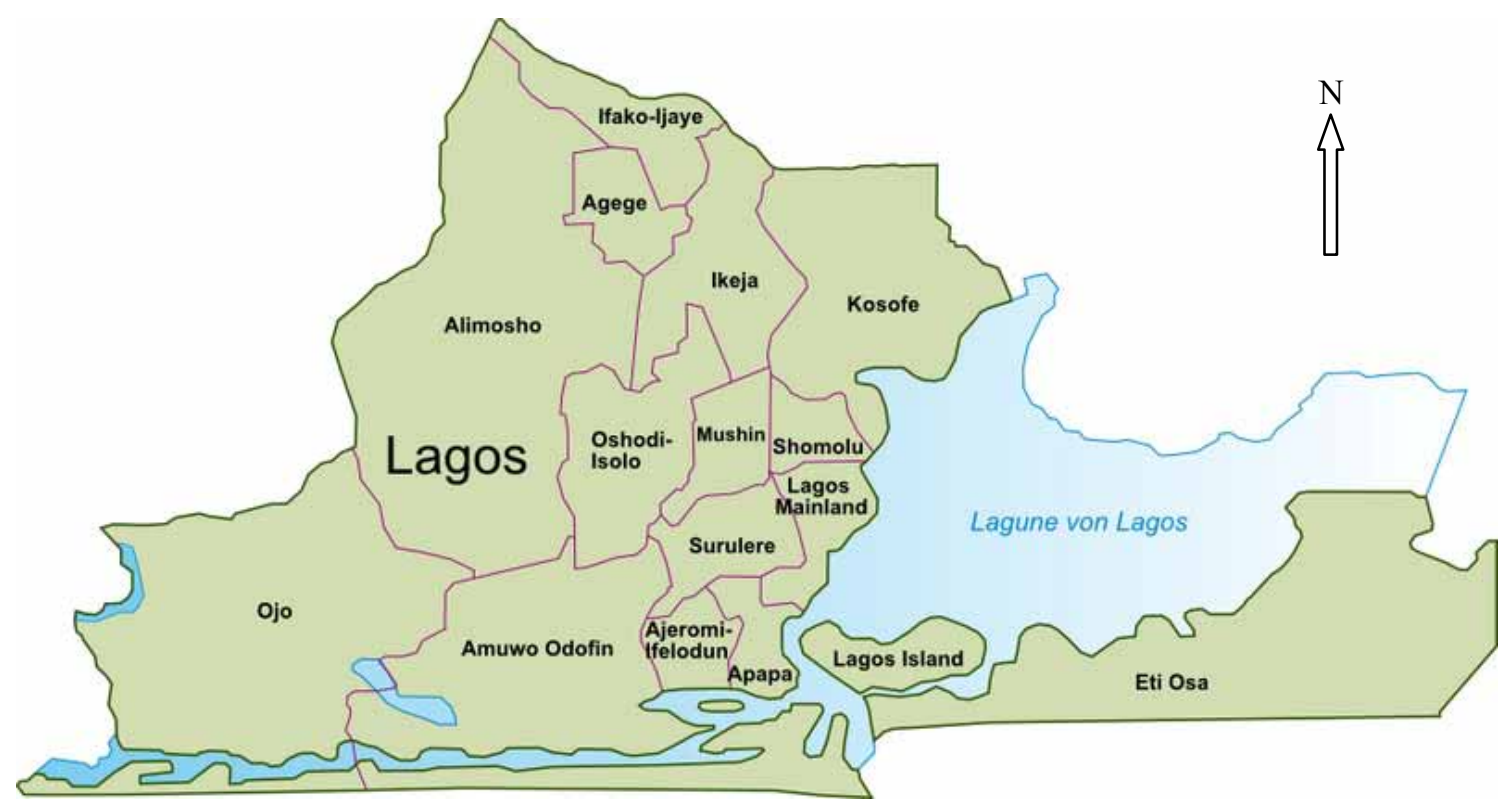

Figure1. Map of Metropolitan Lagos

Source: Lagos State Ministry of Information. 